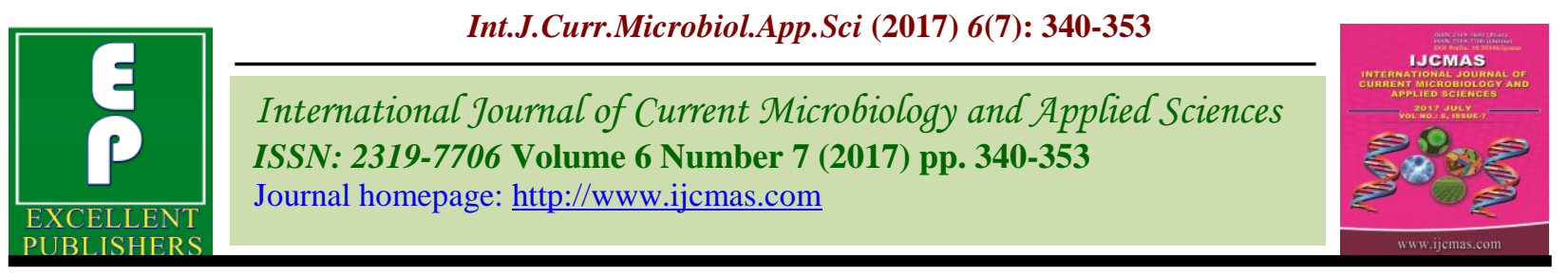

Review Article

https://doi.org/10.20546/ijcmas.2017.607.040

\title{
Enhancing Bio-Availability of Vitamin D by Nano-Engineered Based Delivery Systems- An Overview
}

\author{
Vaibhav Kumar Maurya and Manjeet Aggarwal*
}

Department of Basic and Applied Science, National Institute of Food Technology, Entrepreneurship and Management, Kundli, Sonepat 131028, Haryana, India

*Corresponding author

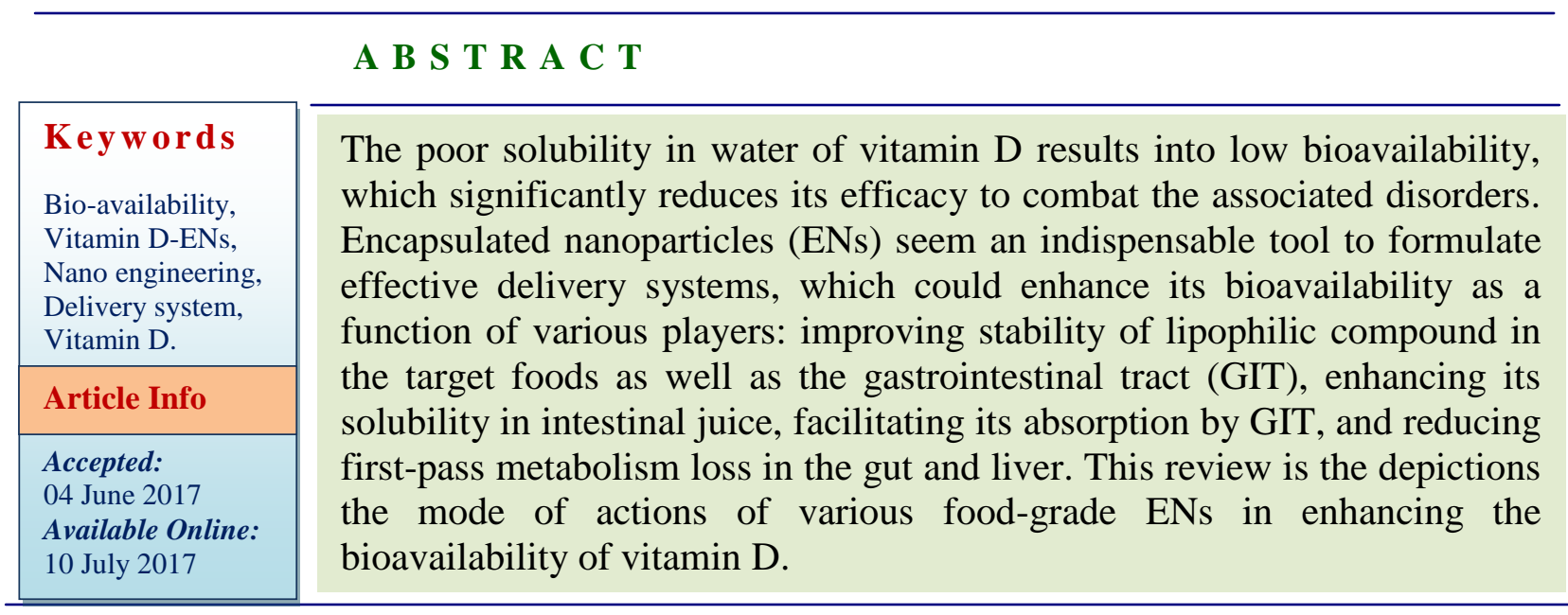

\section{Introduction}

Cholecalciferol, ergocalciferol, and hydroxylated vitamin D $[25(\mathrm{OH})$ D3] contribute significantly in dietary vitamin D and in combination referred as total dietary vitamin D. Molecular structure is recalled in figure 1. Vitamin D is incorporated in various foods and supplements to improve their bioavailability.

These functional foods designed to provide health benefits beyond basic nutrition (KayaCeliker and Mallikarjunan, 2012). Accruing evidences have acclaimed that dietary consumption of vitamin $\mathrm{D}$ is linked with low risks of multiple chronic diseases (Calvo et al., 2013; Green et al., 2010; Hohman et al.,
2011; Jasinghe et al., 2005; Keane et al., 1998; Keegan et al., 2013; Ko et al., 2008; Koyyalamudi et al., 2009; Lehtonen-Veromaa et al., 2008; Natri et al., 2006; Outila et al., 1999; Stephensen et al., 2012; Urbain et al., 2011). Nevertheless, vitamin D has poor bioavailability, which significantly reduces its efficacy as disease-combating agents (Holick 2004; Hollander et al., 1978).

An effective way to enhance bioavailability of vitamin $\mathrm{D}$ is to exploit nanotechnology to encapsulate vitamin $\mathrm{D}$ in engineered nanoparticles (ENs)-based delivery systems (Ghosh et al., 2011; Joye et al., 2014; Öztürk 2017). 
Nano-engineered delivery systems for vitamin D

Nanotechnology has become an indispensable means of engineering novel materials and structures for a wide range of applications within the food industry to ensure its growth (Chaudhry and Castle, 2011). Several ENs have been designed and tested for their potential use as delivery systems for vitamin $\mathrm{D}$ with the aim of improving its health benefits via encapsulation, protection and/or controlled/sustained release (Gonnet et al., 2010; Reza Mozafari et al., 2008). Enhancing bioavailability of vitamin $\mathrm{D}$ has become an encouraging approach to improving their efficacy in humans. Recently, significant developments have been achieved in engineering ENs to escalate bioavailability of vitamin D (Guttoff et al., 2015; MenéndezAguirre et al., 2014). Generally, based on the presence or absence of lipids as the major components of the delivery systems, ENs is categorized as lipid-derived or non-lipidderived (Table 1). Recent literature has depicted inclusive representations of the manufacture and characteristics of different type of ENs compatible with target food(Abbasi et al., 2014; Acosta 2009; Domingues 2013; Farhang 2013; Gonnet et al., 2010; Ozturk et al., 2015; Thompson et al., 2009). Present review illustrates the impact of ENs on bioavailability. It is remarkable that ENs for food application has to be prepared with $100 \%$ food-grade materials, such as edible lipids, proteins, carbohydrates, and surfactants unlikely to ENs utilized in the pharmaceutical industry, this significantly carries challenges in designing effective delivery systems.

\section{Bioavailability of vitamin D}

The bioavailability of vitamin $\mathrm{D}$ can be defined as the proportion of the ingested vitamin that actually reaches the systemic (blood) circulation in an active form. Only then, the vitamin $\mathrm{D}$ will be available to distribute to the target tissues and organs where they can execute their beneficial health effects. For ingested vitamin D, there are few challenges, which avert it in reaching the systemic circulation as an active form, e.g. chemical instability through digestion process, poor solubility in gastrointestinal tract (GIT) liquids, slow absorption from the GIT, and first-pass metabolism (Figure 3). The oral bioavailability $(F)$ of encapsulated vitamin D in ENs can be determined by the following equation

$F=F_{\mathrm{B}} \mathrm{X} F_{\mathrm{A}} \mathrm{X} F_{\mathrm{M}}$

Here, $F_{\mathrm{B}}$ is the proportion of an ingested vitamin $\mathrm{D}$ that subsists through the upper GIT and that is released from the food matrix/ENs into the GIT, therefore becoming bio accessible for absorption by brush-bordered enterocytes. $F_{\mathrm{A}}$ is the proportion of the bio accessible vitamin $\mathrm{D}$, which is actually absorbed by the enterocytes and then reached to the portal blood or lymph (and into the systemic circulation). $F_{\mathrm{M}}$ is the proportion absorbed vitamin $\mathrm{D}$ which retains in an active form after first-pass metabolism in the GIT and liver (and any other forms of metabolism). The effects of food-grade ENbased delivery systems on absorption, bio accessibility and first-pass metabolism of vitamin D-ENs will be discoursed.

\section{Mechanism of absorption of vitamin D}

Initially the mechanism of absorption of vitamin $\mathrm{D}$ is assumed to be medicated by an unsaturable passive diffusion process. However, this hypothesis is disproved by recent literature on human intestinal cell line $\mathrm{CaCO}_{2}$ and $\mathrm{HEK}$ transfected cells that clearly indicate the relation of intestinal cell membrane protein in the absorption of vitamin $\mathrm{D}$ at the border side of the 
enterocytes. Absorption of cholesterol and other lipophilic compounds (tocopherol, carotenoids) is also facilitated by these proteins which are SR-BI (scavenge receptor class B type 1), CD 36 (cluster Determinant 36) and NPC1L1 (Neimann-Pick C1-Like 1). Nevertheless, there is limited data available on the mechanism how the absorption of other lipophilic compounds influences the vitamin $\mathrm{D}$ absorption through these proteins.

The observations made from these proteins postulate that there is a mode shift in absorption of vitamin $\mathrm{D}$ from protein mediated transport to passive diffusion, depending on the concentration of vitamin D: protein mediated transport at low concentration (dietary concentration of vitamin D) and passive diffusion at high concentration (pharmacological concentration) (Reboul et al., 2011). Further the difference in vitamin $\mathrm{D}$ uptake between jejunum and duodenum clearly indicates the presence of another transporter particularly expressed in the jejunum (Goncalves et al., 2015). More research on these transporters is required to understand complete mechanism of vitamin D uptake in intestine.

\section{Enhancing bio accessibility of vitamin D by nano engineering}

Vitamin D-ENs is subjected to a variety of changes in the composition, structure and flow behavior as it passages through the GIT. These variations may cause alteration in the physical and chemical status of the vitamin D, hence reducing its bio accessibility. The fate of vitamins D in GIT is watched by those factors which have been intimately involved with major lipid (phospholipid and triglycerides) (Niramitmahapanya et al., 2011; Tso and Fujimoto, 1991). These involve emulsification, dissolution in micelles, diffusion through the stagnant water layer and penetration across enterocytes membranes (Khalid et al., 2015). The future of vitamin D in GIT appears to be a multistage process counting physiochemical as well as enzymatic involvement (Figure 2). The acidic $\mathrm{pH}$ of gastric juice may affect the bioavailability of vitamin D. Further, a hypothesis is made that protein digestive enzymes (pepsin and trypsin) are also intimately involved in releasing encapsulated vitamin D from protein-based delivery system. Due to fat-soluble nature of vitamin $\mathrm{D}$, it is also assumed that vitamin $\mathrm{D}$ will be more bioavailable if it is incorporated in lipidbased delivery system. Hence, ENs has been engineered to protect vitamin $D$ from unfavorable GIT conditions. Encapsulation of vitamin $\mathrm{D}$ in nano liposomes developed from food grade materials decreased its degradation in simulated intestinal fluids. Vitamin D is also encapsulated in solid lipid nanoparticles and biopolymer-based nanoparticles that can be designed to protect them from premature release and enhance its stability in the GIT.

Before absorption of vitamin $\mathrm{D}$ by enterocytes, it needs to be solubilized in GIT fluids in order to be bio accessible to enterocyte. Lipophilic nature of vitamin D exerts low bio accessibility due to their poor solubility in aqueous GIT fluids. Lipid-based ENs, such as nano emulsions, liposome, micelles and solid lipid nanoparticles, has recently been used to improve the bio accessibility of lipophilic vitamins (Müllertz et al., 2010; Santos and Meireles, 2010). The nature of the carrier oil applied to solubilize lipophilic vitamins within lipid-based ENs also impacts their loading capacity and bio accessibility (Qian et al., 2012; Yang and McClements, 2013). After ingestion, the compositions, structures and physiochemical properties of vitamin-loaded ENs may be altered significantly as it is subjected to different GIT conditions, e.g. their aggregation state, charge, physical state, and size. The attendance of digestible constituents 
(protein, lipid and surfactant) is also key to determine the biological fate of lipid-based ENs in the GIT, which in turn has a great influence on the bioaccessibility of vitamin D(McClements et al., 2007; Yao et al., 2014). In general, digestible carrier oils (primarily triglycerides) in ENs are hydrolyzed by lipases to produce free fatty acids and mono acylglycerols in GIT. These digested lipid products interact with bile salts and phospholipids in the small intestine to produce "mixed micelles" with complex structures (Yao et al., 2014). Vitamins encapsulated within ENs are transferred to the mixed micelles during the digestion process, which boosts their bio accessibility. The variety of carrier oils used in ENs is crucial for the bio accessibility of lipophilic vitamins. Nano emulsions comprising mainly long chain triglycerides exerted much higher bio accessibility of vitamin $\mathrm{E}, \beta$-carotene and Coenzyme Q10 than those comprising mainly medium chain triglycerides (Cho et al., 2014; Qian et al., 2012; Yao et al., 2014). These findings indicate that the nature of carrier oils is the key to bio accessibility of vitamins; hence, EN-based delivery systems should be specific for vitamin D in order to enhance its bio accessibility. It is also assumed that the particle size of ENs may also influence vitamin D bio accessibility. This assumption was tested by various studies in which the nano emulsions with smaller particles have been document to exhibit a higher bio accessibility of $\beta$-carotene than those with larger particles (Salvia-Trujillo et al., 2013). This phenomenon can be explained by the hypothesis which assumes that the smaller lipid particles create mixed micelles more rapidly than larger particles during lipid digestion, which can improve the rate of transfer of the vitamins from the particles to the mixed micelles. Further, it was also assumed that the surfactants used in oil-inwater Nano emulsions might influence the bio accessibility of encapsulated vitamin. This assumption was tested in simulated study in which it was found that the extent to which carrier triglyceride oil was digested in a simulated GI tract was inversely correlated to aliphatic chain length of the surfactant and positively correlated with the hydrophilic/lipophilic balance of the surfactant (Speranza et al., 2013). The difference in the oil digestion may cause variation in the solubilization of vitamins in mixed micelles, consequently in different bio accessibility. Therefore, appropriate surfactants can be selected for specific nano emulsions for desired bio accessibility. Moreover, biopolymer-based non-lipid delivery systems are primarily applied to improve bio accessibility by enhancing solubility of vitamin D.

\section{Improving the absorption of vitamin D: Engineered nanoparticles}

The small intestine is the site of absorption for lipophilic vitamins after their oral ingestion (Goncalves et al., 2011; Goncalves et al., 2015). Figure 3 illustrates the main routes of absorption in the small intestine. Lipid-derived ENs (Nano emulsions) have been widely used to encapsulate lipophilic vitamin $\mathrm{D}$ to improve their absorption (Farhang 2013; Kiani et al., 2016). Mixed micelles produced in consequence to digestion of Nano emulsions transport these lipophilic vitamins through the aqueous mucous layer, and make them bioavailable to brush bordered enterocytes for absorption. Furthermore these transported vitamins are encased into chylomicrons within the enterocytes as result of their high hydrophobicity (Pouton and Porter, 2008; Yáñez et al., 2011). These chylomicrons are lipid particles are endogenously generated inside the enterocytes exploiting lipid components (free fatty acids, mono acyglycerols, and cholesterol) of mixed micelles generated as result of fat digestion 
(Yao et al., 2013). Further, these chylomicrons comprising vitamins are transported to the lymphatic circulation system via a chylomicron-mediated pathway. It is hypothesized that the presence of mixed micelles, which is the function of free fatty acids and bile acids, improves the transenterocyte transport of lipophilic compounds. This hypothesis was verified by 3-fold increase in bioavailability of lipophilic flavonoid 5-hydroxy-6,7,8,3,4-pentamethoxyl flavone of citrus fruit in Caco-2 cell line (Yao et al., 2013). This enhancement in absorption was highly correlated with production of chylomicron in the enterocytes triggered by the mixed micelles. Furthermore, it is also assumed that the degree of saturation of fatty acids in mixed micelles is a key factor influencing the absorption of vitamin D.

In order to test this assumption a study was performed on transport of 5-hydroxylnobiletin through mixed micelles formed with oleic acid, linoleic acid, or linolenic acid and it was observed that transport of 5-hydroxylnobiletin is influenced by the degree of saturation and chain length of fatty acid. Mixed micelles developed with oleic acid exhibit higher trans-enterocyte transport of 5hydroxylnobiletin than mixed micelles developed with linoleic acid or linolenic acid Simultaneously it is also believed that some fraction of vitamin D still persists inside undigested nanoparticle rather than being released during passage of GIT (Harde et al., 2011). Further vitamin D-ENs is suspected to transported paracellularly to the portal blood via tight junctions, or taken up by $\mathrm{M}$ cells via Peyer's patches and then secreted into the lymph. Additionally it is suspected that some compounds can influence the structure and integrity of intestinal epithelial cells. This assumption was verified for various compound such as chitosan (separate the tight junction components) EDTA (widens intracellular tight junction seals), free fatty acids (increases plasma membrane permeability), surfactants (modulate the integrity of the plasma membrane). Hence properties of these components can be exploited to enhance the absorption of vitamin $\mathrm{D}$ while designing the delivery system. In case digestible ENs, encapsulated vitamins can be released and solubilized within the GIT fluids and then absorbed by the enterocytes via active transport or passive diffusion (Acosta, 2009). Ultimately, vitamin D may be transported directly to the portal blood circulation or via the chylomicronmediated lymphatic transport.

Fig.1 Chemical structures of naturally occuring dietary forms of vitamin D (I) Cholecalciferol, (II) $25(\mathrm{OH})$ cholecalciferol, and (III) ergocalciferol

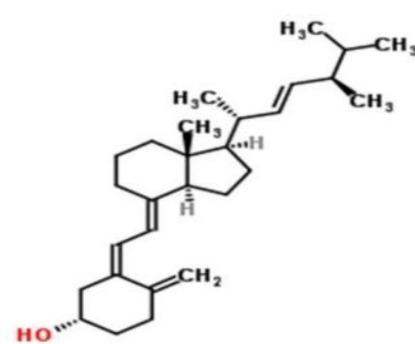

(I)
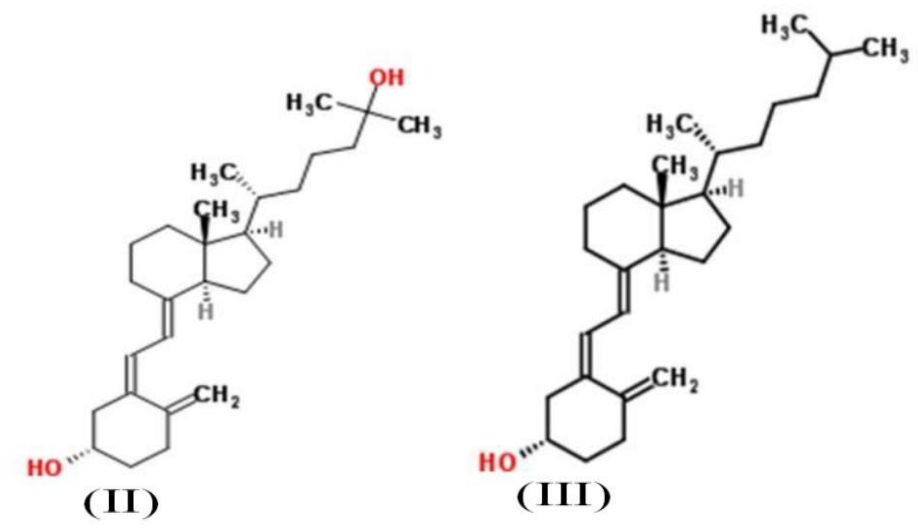
Table.1 Engineered nanoparticles based delivery systems for Enhancing bioavailability Vitamin D

\begin{tabular}{|c|c|c|c|c|c|}
\hline $\begin{array}{l}\text { Class of } \\
\text { delivery }\end{array}$ & $\begin{array}{l}\text { Subclass of } \\
\text { delivery } \\
\text { system }\end{array}$ & $\begin{array}{l}\text { Delivery } \\
\text { system }\end{array}$ & Ingredients & $\begin{array}{l}\text { Function } \\
\text { site }\end{array}$ & References \\
\hline \multirow[t]{6}{*}{$\begin{array}{l}\text { Lipid } \\
\text { derived } \\
\text { delivery } \\
\text { system }\end{array}$} & \multirow[t]{2}{*}{$\begin{array}{l}\text { Self-assembled } \\
\text { delivery } \\
\text { system }\end{array}$} & Liposome & $\begin{array}{l}\text { Phospholipids, } \\
\text { propylene glycol } \\
\text { and polysorbate 80, } \\
\text { Milk Fat Globule } \\
\text { Membrane-Derived } \\
\text { Phospholipids }\end{array}$ & $\mathrm{F}_{\mathrm{B}}$ & $\begin{array}{l}\text { (Banville et al., 2000; Farhang, 2013; } \\
\text { Mohammadi et al., 2014; Thompson et } \\
\text { al., 2009; Xia et al., 2011) }\end{array}$ \\
\hline & & Niosome & polysorbate 20 & $\mathrm{~F}_{\mathrm{B}}$ & (Patel et al., 2012; Wagner et al., 2016) \\
\hline & \multirow[t]{2}{*}{ Particulate } & $\begin{array}{l}\text { Solid lipid } \\
\text { nanoparticles }\end{array}$ & $\begin{array}{l}\text { Polyethylene glycol } \\
\text { hydroxyl stearate, } \\
\text { Soybean lecithin, }\end{array}$ & $\mathrm{F}_{\mathrm{A}} \& \mathrm{~F}_{\mathrm{M}}$ & (Kiani et al., 2016; Patel et al., 2012) \\
\hline & & $\begin{array}{l}\text { Nanostructured } \\
\text { lipid carriers }\end{array}$ & $\begin{array}{l}\text { glycerol } \\
\text { monostearate (solid } \\
\text { lipid), and Tween } \\
80\end{array}$ & $\mathrm{~F}_{\mathrm{A}} \& \mathrm{~F}_{\mathrm{M}}$ & (Park et al., 2017) \\
\hline & \multirow[t]{2}{*}{ Emulsion } & $\begin{array}{l}\text { Micro } \\
\text { emulsion }\end{array}$ & triacylglycerol oil & $\mathrm{F}_{\mathrm{B}}$ & (Khalid et al., 2015) \\
\hline & & Nanoemulsion & $\begin{array}{l}\text { Q-Naturale, medium } \\
\text { chain triglycerides } \\
(\mathrm{MCT}), \text { corn } \\
\text { oil } \approx \text { fish oil, orange } \\
\text { oil, mineral oil. }\end{array}$ & $\mathrm{F}_{\mathrm{B}} \& \mathrm{~F}_{\mathrm{A}}$ & (Ozturk et al., 2015; Shu et al., 2016) \\
\hline \multirow{9}{*}{$\begin{array}{l}\text { Polymer } \\
\text { derived } \\
\text { delivery } \\
\text { system }\end{array}$} & \multirow{5}{*}{$\begin{array}{l}\text { Self-assembled } \\
\text { delivery } \\
\text { system }\end{array}$} & Micelle & $\begin{array}{l}\text { Oleoyl alginate } \\
\text { ester (OAE) }\end{array}$ & $\mathrm{F}_{\mathrm{B}} \& \mathrm{~F}_{\mathrm{A}}$ & (Li et al., 2011) \\
\hline & & $\begin{array}{l}\text { Protein based } \\
\text { micelles }\end{array}$ & $\begin{array}{l}\text { whey protein isolate, } \\
\text { casein, } \\
\text { carboxymethyl } \\
\text { chitosan, }\end{array}$ & $\mathrm{F}_{\mathrm{B}} \& \mathrm{~F}_{\mathrm{A}}$ & $\begin{array}{l}\text { (Abbasi et al., 2014; Haham et al., } \\
\text { 2012; Luo et al., 2012; Menéndez- } \\
\text { Aguirre et al., 2014) }\end{array}$ \\
\hline & & Hydrogel & & $\mathrm{F}_{\mathrm{B}}, \mathrm{F}_{\mathrm{A}} \& \mathrm{~F}_{\mathrm{M}}$ & (Li et al., 2011) \\
\hline & & $\begin{array}{l}\text { Colloidal } \\
\text { nanoemulsion }\end{array}$ & $\begin{array}{l}\text { Carboxymethyl } \\
\text { chitosan-soy protein }\end{array}$ & $\mathrm{F}_{\mathrm{B}}, \mathrm{F}_{\mathrm{A}} \& \mathrm{~F}_{\mathrm{M}}$ & (Teng et al., 2013; Ziani et al., 2012) \\
\hline & & Nano emulsion & & $\mathrm{F}_{\mathrm{B}} \& \mathrm{~F}_{\mathrm{A}}$ & $\begin{array}{l}\text { (Guttoff } \text { et al., 2015; Park et al., 2017; } \\
\text { Sun } \text { et al., 2012) }\end{array}$ \\
\hline & \multirow[t]{2}{*}{ Particulate } & Nanosphere & $\begin{array}{l}\text { Poly (D,L-lactide- } \\
\text { co-glycolide) } \\
\text { (PLGA }\end{array}$ & $\mathrm{F}_{\mathrm{B}} \& \mathrm{~F}_{\mathrm{A}}$ & (Domingues, 2013) \\
\hline & & microsphere & $\beta$-lactoglobulin & $\mathrm{F}_{\mathrm{B}} \& \mathrm{~F}_{\mathrm{A}}$ & $\begin{array}{l}\text { (Diarrassouba } \text { et al., 2015; Shi and Tan, } \\
\text { 2002) }\end{array}$ \\
\hline & \multirow[t]{2}{*}{ Capsular } & Microcapsule & $\begin{array}{l}\text { Fatty acid esters of } \\
\text { glycerol and PEG } \\
\text { ester }\end{array}$ & $\mathrm{F}_{\mathrm{A}}$ & (Bishop et al., 2013) \\
\hline & & Nanocapsule & $\begin{array}{l}N, N \text {-dialkyl- } N, N \text { - } \\
\text { diacetate } \\
\text { ethylenediamine }\end{array}$ & $\mathrm{F}_{\mathrm{A}}$ & (Lv et al., 2016) \\
\hline
\end{tabular}


Fig.2 Schematic diagram of the human digestive system and the various physiochemical and physiological processes involved in digestion and absorption of vitamin $\mathrm{D}$
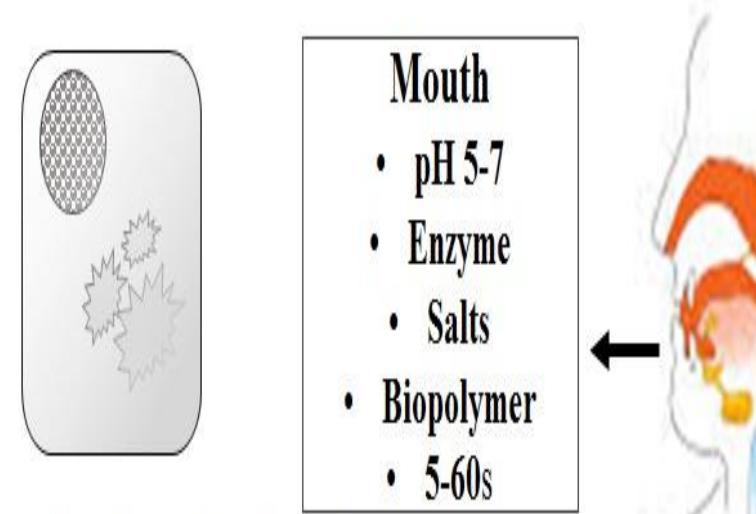

\section{Food matrix disruption}
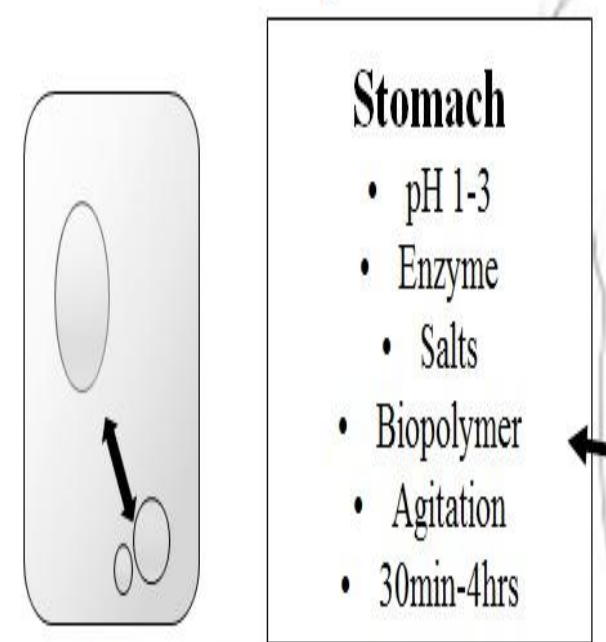

Dropletformation and Dissuption

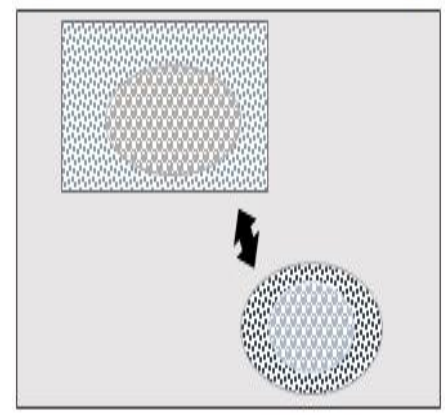

Competitiveadsorption \& Displacement

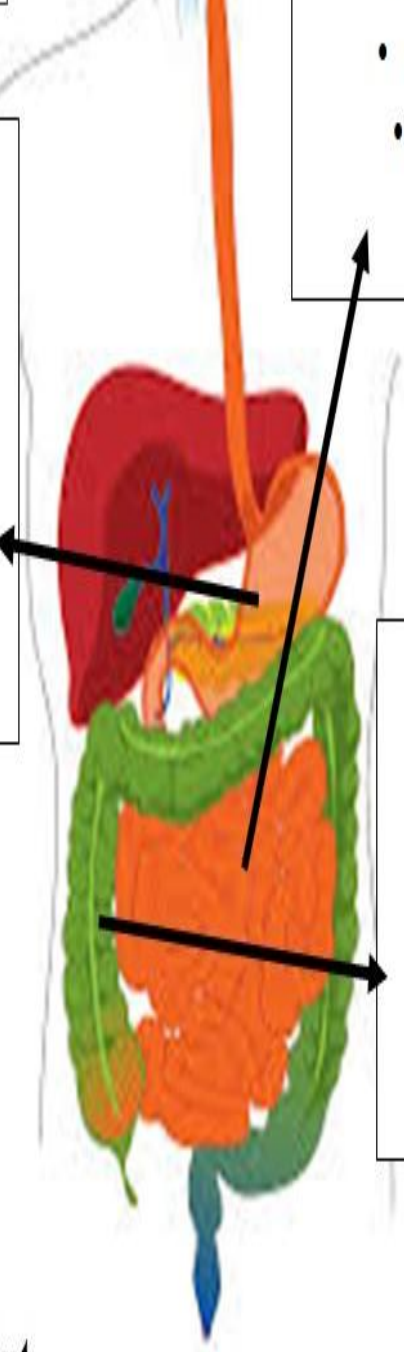

Small intestine

- $\mathrm{pH} 6-7.5$

- Enyyme

- Bile, Salts

- Biopolymer

- Aggitation

- 1-2hrs

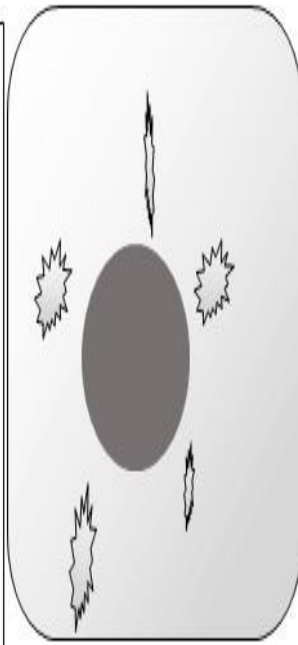

Enzyme adsorption and activity

\section{Colon}

- pH5-7

- Enzyme

- Bacteria

- Agitation

- 12-24hrs 
Fig.3 The fate of encapsulated vitamin $\mathrm{D}$ in intestinal lumen. Where $\mathbf{F}_{\mathbf{B}}$ : fraction of the encapsulated vitamin $\mathrm{D}$ which released from food matrix into the gastric juice in GIT, $\mathbf{F}_{\mathrm{A}}$ :

fraction of the vitamin which is transported through the intestinal epithelium and then transported to the portal or lymph, $\mathbf{F}_{\mathbf{M}}$ : The fraction absorbed vitamin D which is an active form after bypass the chemical modification by organs such as liver and kidney




Minimizing the first-pass metabolism of vitamin $D$ by Nano engineering

First-pass metabolism (also called as firstpass elimination) is a process during which a syndicate of enzymes, present mainly in the gut and liver, metabolizes a drug (Figure 3). First-pass metabolism is responsible for decreased oral bioavailability as it causes degradation of most of the ingested drugs and resulting into a fraction of ingested drug reaches the systemic circulation in active form. Vitamin-ENs can be engineered to bypass the first-pass metabolism and thus improving their bioavailability. Lipid-derived ENs, such as Nano emulsions, has been widely used to bypass liver metabolism by endorsing intestinal lymphatic transport of lipophilic compounds (Yao et al., 2014). In addition to this, Nano emulsions also promote the chylomicron-mediated transport of lipophilic compounds from enterocytes to the lymphatic circulation. Consequently, lymph carries chylomicron-associated lipophilic compound to the systemic circulation via the subclavian vein evading the liver enzyme catalysis, thus avoiding first-pass metabolism in the liver (Figure 3)(Porter et al., 2007). Thus, ENs can also shield vitamin D from first-pass metabolism in enterocytes. Further ENs can escalate paracellular transport of vitamins by altering the integrity of tight junctions if nanoparticles are derived by some specific materials. It is believed that paracellularly transported lipophilic compounds are not exposed to metabolic activity of intracellular enterocyte enzymes, and may therefore have higher bioavailability. ENs (Nano emulsions, liposomes etc.) that promote chylomicron-mediated transport of lipophilic compounds, may also reduce firstpass metabolism in the enterocytes. This is the reason that vitamin associated with the chylomicrons may have less chance to interact with metabolizing enzymes within the cell in comparison to vitamins freely present in the cytoplasm of enterocytes (Sun et al., 2015; Yao et al., 2015). Moreover, it believed that the type of carrier oil of these nanoparticles is crucial in the first-pass metabolism of lipophilic compound in the enterocytes. This was verified by study on olive oil-based Nano emulsion which resulted in a minimal metabolism of pterostilbene (an important phenolic bioactive compound present in blue berries) in enterocytes, whereas flaxseed oil-based Nano emulsion resulted in an extensive metabolism of pterostilbene (Sun et al., 2015). In order to deliver optimized dose of vitamin D with enhanced bioavailability by decreasing firstpass metabolism, more mechanistic investigations are needed to establish the relationship between the different characteristics of ENs and their effects on first-pass metabolism of vitamin D.

Accruing research has illustrated that foodgrade engineered nanoparticles can be employed to enhance the bioavailability of lipophilic vitamin D, which may improve their potential health benefits in humans to combat the associated disorders. More systematic mechanistic approach is needed to explicate the correlation between the particle characteristics of ENs and their impact on the biological fate of encapsulated lipophilic vitamin D. Update in this area would provide a solid scientific ground for the rational design of novel EN-based delivery systems to enhance the efficacy of vitamin D.

\section{Future research prospects}

After thorough review of literature, the gaps in present literature were identified and these research gaps could be addressed by future dedicated studies. The future research prospects identified from present literature are as follows: 
The acidic $\mathrm{pH}$ of gastric juice may affect the bioavailability of encapsulated vitamin $\mathrm{D}$. It is apparent that few data available on the susceptibility of vitamin D-ENs with respect to $\mathrm{pH}$ variation in GIT.

It have been observed that various digestive enzymes facilitate the release of vitamin D from vitamin D-ENs but the role of these enzymes is not fully recognized with respect to bioavailability of vitamin D-ENs. The evaluation of effect of enzymes individually or in syndicate and their concentration on vitamin D-ENs bioavailability will aid better understanding in designing better delivery system for vitamin D.

In duodenum digestive enzyme (amylases, lipase and protease) continues the release of polymer derived vitamin D-ENs. Vitamin D released vitamin D-ENs during digestion need to transfer from oil (naturally retained in dietary lipid) to the fat phase of meal (micelles). Nevertheless, kinetics of vitamin D transfer from food matrix into micelles is not completely understood. More dedicated research is needed to get better understanding about the impact of vitamin $\mathrm{D}$ transfer from food oil phase to micelle on the bioavailability of vitamin $\mathrm{D}$.

Though vitamin D-ENs exhibit high bioavailability that molecular vitamin $\mathrm{D}$ but the presence of other lipophilic compound may affect the bioavailability of vitamin D. More studies, illustrating the impact of lipophilic compounds present in food matrix on bioavailability of vitamin D-ENs, will be helpful in designing better delivery system for vitamin D.

The nature of carrier oil ((fatty acid chain length and degree of saturation) has great impact on determining the biological fate of lipid derived ENs (Ozturk et al., 2015). However, few data is available with reference to lipid based vitamin D nanoparticle in order to draw a firm conclusion.

Certain substances (EDTA, chitosan, fatty acid etc.) can modulate the structure and integrity of plasma membrane. This is least explored field and can be exploited in designing vitamin $\mathrm{D}-\mathrm{ENs}$ to enhance the bioavailability of vitamin $\mathrm{D}$.

\section{References}

Abbasi A, Emam-Djomeh Z, Mousavi MAE, Davoodi D (2014) Stability of vitamin D3 encapsulated in nanoparticles of whey protein isolate Food Chemistry 143:379383 doi:http://dx.doi.org/10.1016/j.food chem.2013.08.018

Acosta E (2009) Bioavailability of nanoparticles in nutrient and nutraceutical delivery Current opinion in colloid and interface science 14:3-15

Banville C, Vuillemard J, Lacroix C (2000) Comparison of different methods for fortifying Cheddar cheese with vitamin D International Dairy Journal 10:375-382

Bishop CW, Tabash SP, Agudoawu SA, White JA, Crawford KH, Messner EJ, Petkovich PM (2013) Methods and compositions for controlled release oral dosage of a vitamin D compound. Google Patents,

Calvo M, Babu U, Garthoff L, Woods T, Dreher M, Hill G, Nagaraja S (2013) Vitamin D2 from light-exposed edible mushrooms is safe, bioavailable and effectively supports bone growth in rats Osteoporosis international 24:197-207

Chaudhry Q, Castle L (2011) Food applications of nanotechnologies: an overview of opportunities and challenges for developing countries Trends in Food Science and Technology 22:595-603

Cho H, Salvia-Trujillo L, Kim J, Park Y, Xiao H, McClements D (2014) Droplet size and composition of nutraceutical nanoemulsions influences bioavailability of long chain fatty acids and Coenzyme Q10 Food chemistry 156:117-122 
Diarrassouba F, Garrait G, Remondetto G, Alvarez P, Beyssac E, Subirade M (2015) Food protein-based microspheres for increased uptake of vitamin D3 Food Chemistry 173:1066-1072 doi:http://dx. doi.org/10.1016/j.foodchem.2014.10.112

Domingues NJA (2013) Carrier Systems for Vitamin D. Citeseer,

Farhang B (2013) Encapsulation of Bioactive Compounds in Liposomes prepared with Milk Fat Globule Membrane-Derived Phospholipids.

Ghosh I, Bose S, Vippagunta R, Harmon F (2011) Nanosuspension for improving the bioavailability of a poorly soluble drug and screening of stabilizing agents to inhibit crystal growth International Journal of Pharmaceutics 409:260-268 doi:http://dx.doi.org/10.1016/j.ijpharm.20 11.02.051

Goncalves A et al., (2011) Phytosterols can impair vitamin D intestinal absorption in vitro and in mice Molecular nutrition and food research 55:S303-S311

Goncalves A, Roi S, Nowicki M, Dhaussy A, Huertas A, Amiot M-J, Reboul E (2015) Fat-soluble vitamin intestinal absorption: absorption sites in the intestine and interactions for absorption Food chemistry 172:155-160

Gonnet M, Lethuaut L, Boury F (2010) New trends in encapsulation of liposoluble vitamins Journal of Controlled Release 146:276-290

Green TJ, Skeaff CM, Rockell JE (2010) Milk fortified with the current adequate intake for vitamin D $(5 \mu \mathrm{g})$ increases serum 25 hydroxyvitamin $\mathrm{D}$ compared to control milk but is not sufficient to prevent a seasonal decline in young women Asia Pacific journal of clinical nutrition 19:195-199

Guttoff M, Saberi AH, McClements DJ (2015) Formation of vitamin D nanoemulsionbased delivery systems by spontaneous emulsification: Factors affecting particle size and stability Food Chemistry 171:117-122 doi:http://dx.doi.org/ 10.1016/j.foodchem.2014.08.087
Haham M, Ish-Shalom S, Nodelman M, Duek I, Segal E, Kustanovich M, Livney YD (2012) Stability and bioavailability of vitamin $D$ nanoencapsulated in casein micelles Food and function 3:737-744

Harde H, Das M, Jain S (2011) Solid lipid nanoparticles: an oral bioavailability enhancer vehicle Expert opinion on drug delivery 8:1407-1424

Hohman EE, Martin BR, Lachcik PJ, Gordon DT, Fleet JC, Weaver CM (2011) Bioavailability and efficacy of vitamin D2 from UV-irradiated yeast in growing, vitamin D-deficient rats Journal of agricultural and food chemistry 59:23412346

Holick MF (2004) Vitamin D: importance in the prevention of cancers, type 1 diabetes, heart disease, and osteoporosis The American journal of clinical nutrition 79:362-371

Hollander D, Muralidhara K, Zimmerman A (1978) Vitamin D-3 intestinal absorption in vivo: influence of fatty acids, bile salts, and perfusate $\mathrm{pH}$ on absorption Gut 19:267-272

Jasinghe VJ, Perera CO, Barlow PJ (2005) Bioavailability of vitamin D2 from irradiated mushrooms: an in vivo study The British journal of nutrition 93:951

Joye IJ, Davidov-Pardo G, McClements DJ (2014) Nanotechnology for increased micronutrient bioavailability Trends in Food Science and Technology 40:168182 doi:http://dx.doi.org/10.1016/j.tifs. 2014.08.006

Kaya-Celiker H, Mallikarjunan K (2012) Better nutrients and therapeutics delivery in food through nanotechnology Food Engineering Reviews 4:114-123

Keane E, Healy M, O'moore R, Coakley D, Walsh J (1998) Vitamin D-fortified liquid milk: benefits for the elderly communitybased population Calcified tissue international 62:300-302

Keegan R-JH, Lu Z, Bogusz JM, Williams JE, Holick MF (2013) Photobiology of vitamin $\mathrm{D}$ in mushrooms and its bioavailability in humans Dermato- 
endocrinology 5:165-176

Khalid N, Kobayashi I, Wang Z, Neves MA, Uemura K, Nakajima $M$, Nabetani $H$ (2015) Formulation characteristics of triacylglycerol oil-in-water emulsions loaded with ergocalciferol using microchannel emulsification Rsc Advances 5:97151-97162

Kiani A, Fathi M, Ghasemi SM (2016) Production of novel vitamin D3 loaded lipid nanocapsules for milk fortification International Journal of Food Properties

Ko J, Lee B, Lee J, Park HJ (2008) Effect of UV-B exposure on the concentration of vitamin D2 in sliced shiitake mushroom (Lentinus edodes) and white button mushroom (Agaricus bisporus) Journal of agricultural and food chemistry 56:36713674

Koyyalamudi SR, Jeong S-C, Song C-H, Cho KY, Pang G (2009) Vitamin D2 formation and bioavailability from Agaricus bisporus button mushrooms treated with ultraviolet irradiation J Agric Food Chem 57:3351-3355

Lehtonen-Veromaa M, Möttönen T, Leino A, Heinonen OJ, Rautava E, Viikari J (2008) Prospective study on food fortification with vitamin $\mathrm{D}$ among adolescent females in Finland: minor effects British journal of nutrition 100:418-423

Li Q, Liu C-G, Huang Z-H, Xue F-F (2011) Preparation and characterization of nanoparticles based on hydrophobic alginate derivative as carriers for sustained release of vitamin D3 Journal of agricultural and food chemistry 59:19621967

Luo Y, Teng Z, Wang Q (2012) Development of zein nanoparticles coated with carboxymethyl chitosan for encapsulation and controlled release of vitamin D3 Journal of Agricultural and Food Chemistry 60:836-843

Lv J, Qiao W, Li Z (2016) Vesicles from $\mathrm{pH}$ regulated reversible gemini amino-acid surfactants as nanocapsules for delivery Colloids and Surfaces B: Biointerfaces 146:523-531 doi:http://dx.doi.org/10.101 6/j.colsurfb.2016.06.054

McClements DJ, Decker EA, Weiss J (2007) Emulsion- based delivery systems for lipophilic bioactive components Journal of food science 72:R109-R124

Menéndez-Aguirre O, Kessler A, Stuetz W, Grune T, Weiss J, Hinrichs J (2014) Increased loading of vitamin D 2 in reassembled casein micelles with temperature-modulated high pressure treatment Food research international 64:74-80

Mohammadi M, Ghanbarzadeh B, Hamishehkar H (2014) Formulation of nanoliposomal vitamin D3 for potential application in beverage fortification Advanced pharmaceutical bulletin 4:569

Müllertz A, Ogbonna A, Ren S, Rades T (2010) New perspectives on lipid and surfactant based drug delivery systems for oral delivery of poorly soluble drugs Journal of pharmacy and pharmacology 62:16221636

Natri A-M et al., (2006) Bread fortified with cholecalciferol increases the serum 25hydroxyvitamin $\mathrm{D}$ concentration in women as effectively as a cholecalciferol supplement The Journal of nutrition 136:123-127

Niramitmahapanya S, Harris SS, DawsonHughes B (2011) Type of dietary fat is associated with the 25-hydroxyvitamin D3 increment in response to vitamin D supplementation The Journal of Clinical Endocrinology and Metabolism 96:31703174

Outila TA, Mattila PH, Piironen VI, LambergAllardt CJ (1999) Bioavailability of vitamin $\mathrm{D}$ from wild edible mushrooms (Cantharellus tubaeformis) as measured with a human bioassay The American journal of clinical nutrition 69:95-98

Öztürk B (2017) Nanoemulsions for food fortification with lipophilic vitamins: production challenges, stability, and bioavailability European Journal of Lipid Science and Technology

Ozturk B, Argin S, Ozilgen M, McClements DJ (2015) Nanoemulsion delivery systems 
for oil-soluble vitamins: influence of carrier oil type on lipid digestion and vitamin D 3 bioaccessibility Food chemistry 187:499-506

Park SJ, Garcia CV, Shin GH, Kim JT (2017) Development of nanostructured lipid carriers for the encapsulation and controlled release of vitamin D3 Food Chemistry 225:213-219 doi:http://dx.doi.org/10.1016/j.foodchem. 2017.01.015

Patel MR, Martin- Gonzalez S, Fernanda M (2012) Characterization of ergocalciferol loaded solid lipid nanoparticles Journal of food science 77:N8-N13

Porter CJ, Trevaskis NL, Charman WN (2007) Lipids and lipid-based formulations: optimizing the oral delivery of lipophilic drugs Nature Reviews Drug Discovery 6:231-248

Pouton CW, Porter CJ (2008) Formulation of lipid-based delivery systems for oral administration: materials, methods and strategies Advanced Drug Delivery Reviews 60:625-637

Qian C, Decker EA, Xiao H, McClements DJ (2012) Nanoemulsion delivery systems: Influence of carrier oil on $\beta$-carotene bioaccessibility Food Chemistry 135:1440-1447

Reboul E et al., (2011) Vitamin D intestinal absorption is not a simple passive diffusion: evidences for involvement of cholesterol transporters Molecular nutrition and food research 55:691-702

Reza Mozafari M, Johnson C, Hatziantoniou S, Demetzos C (2008) Nanoliposomes and their applications in food nanotechnology Journal of liposome research 18:309-327

Salvia-Trujillo L, Qian C, Martín-Belloso O, McClements D (2013) Influence of particle size on lipid digestion and $\beta$ carotene bioaccessibility in emulsions and nanoemulsions Food Chemistry 141:1472-1480

Santos DT, Meireles MA (2010) Carotenoid pigments encapsulation: fundamentals, techniques and recent trends Open Chemical Engineering Journal 4:42-50
Shi X-Y, Tan T-W (2002) Preparation of chitosan/ethylcellulose complex microcapsule and its application in controlled release of Vitamin D2 Biomaterials 23:4469-4473 doi:http://dx.doi.org/10.1016/S01429612(02)00165-5

Shu G, Khalid N, Zhao Y, Neves MA, Kobayashi I, Nakajima M (2016) Formulation and stability assessment of ergocalciferol loaded oil-in-water nanoemulsions: Insights of emulsifiers effect on stabilization mechanism Food Research International 90:320-327

Speranza A, Corradini M, Hartman T, Ribnicky D, Oren A, Rogers M (2013) Influence of emulsifier structure on lipid bioaccessibility in oil-water nanoemulsions Journal of agricultural and food chemistry 61:6505-6515

Stephensen CB, Zerofsky M, Burnett DJ, Lin Y-p, Hammock BD, Hall LM, McHugh T (2012) Ergocalciferol from mushrooms or supplements consumed with a standard meal increases 25-hydroxyergocalciferol but decreases 25-hydroxycholecalciferol in the serum of healthy adults The Journal of nutrition 142:1246-1252

Sun F, Ju C, Chen J, Liu S, Liu N, Wang K, Liu $\mathrm{C}$ (2012) Nanoparticles based on hydrophobic alginate derivative as nutraceutical delivery vehicle: vitamin D3 loading Artificial Cells, Blood Substitutes, and Biotechnology 40:113119

Sun Y, Xia Z, Zheng J, Qiu P, Zhang L, McClements DJ, Xiao H (2015) Nanoemulsion-based delivery systems for nutraceuticals: Influence of carrier oil type on bioavailability of pterostilbene Journal of Functional Foods 13:61-70

Teng Z, Luo Y, Wang Q (2013) Carboxymethyl chitosan-soy protein complex nanoparticles for the encapsulation and controlled release of vitamin D3 Food Chemistry 141:524-532 doi:http://dx.doi.org/10.1016/j.foodchem. 2013.03.043

Thompson AK, Couchoud A, Singh H (2009) 
Comparison of hydrophobic and hydrophilic encapsulation using liposomes prepared from milk fat globule-derived phospholipids and soya phospholipids. Dairy Science and Technology 89:99-113

Tso P, Fujimoto K (1991) The absorption and transport of lipids by the small intestine Brain research bulletin 27:477-482

Urbain P, Singler F, Ihorst G, Biesalski H-K, Bertz H (2011) Bioavailability of vitamin D2 from UV-B-irradiated button mushrooms in healthy adults deficient in serum 25-hydroxyvitamin $\quad D$ : a randomized controlled trial European journal of clinical nutrition 65:965-971

Wagner ME, Spoth KA, Kourkoutis LF, Rizvi SS (2016) Stability of niosomes with encapsulated vitamin D3 and ferrous sulfate generated using a novel supercritical carbon dioxide method Journal of Liposome Research 26:261268

Xia F, Jin H, Zhao Y, Guo X (2011) Supercritical Antisolvent-based Technology for Preparation of Vitamin D3 Proliposome and Its Characteristics. Chinese Journal of Chemical Engineering 19:1039-1046 doi:http://dx.doi.org/ 10.1016/S1004-9541(11)60089-X

Yáñez JA, Wang SW, Knemeyer IW, Wirth MA, Alton KB (2011) Intestinal lymphatic transport for drug delivery
Advanced drug delivery reviews 63:923942

Yang Y, McClements DJ (2013) Vitamin E bioaccessibility: influence of carrier oil type on digestion and release of emulsified $\alpha$-tocopherol acetate Food Chemistry, 141:473-481

Yao M, Chen J, Zheng J, Song M, McClements DJ, Xiao H (2013) Enhanced lymphatic transport of bioactive lipids: cell culture study of polymethoxyflavone incorporation into chylomicrons Food and function 4:1662-1667

Yao M, McClements D, Zhao F, Craig R, Xiao $H$ (2015) Controlling the gastrointestinal fate of nutraceutical-enriched lipid nanoparticles: From mixed micelles to chylomicrons The FASEB Journal 29:249.246

Yao M, Xiao H, McClements DJ (2014) Delivery of lipophilic bioactives: assembly, disassembly, and reassembly of lipid nanoparticles. Annual review of food science and technology 5:53-81

Ziani K, Fang Y, McClements DJ (2012) Encapsulation of functional lipophilic components in surfactant-based colloidal delivery systems: Vitamin E, vitamin D, and lemon oil. Food Chemistry 134:11061112 doi:http://dx.doi.org/10.1016/ j.foodchem.2012.03.027

\section{How to cite this article:}

Vaibhav Kumar Maurya and Manjeet Aggarwal. 2017. Enhancing Bio-Availability of Vitamin D by Nano-Engineered Based Delivery Systems- An Overview. Int.J.Curr.Microbiol.App.Sci. 6(7): 340-353. doi: https://doi.org/10.20546/ijcmas.2017.607.040 